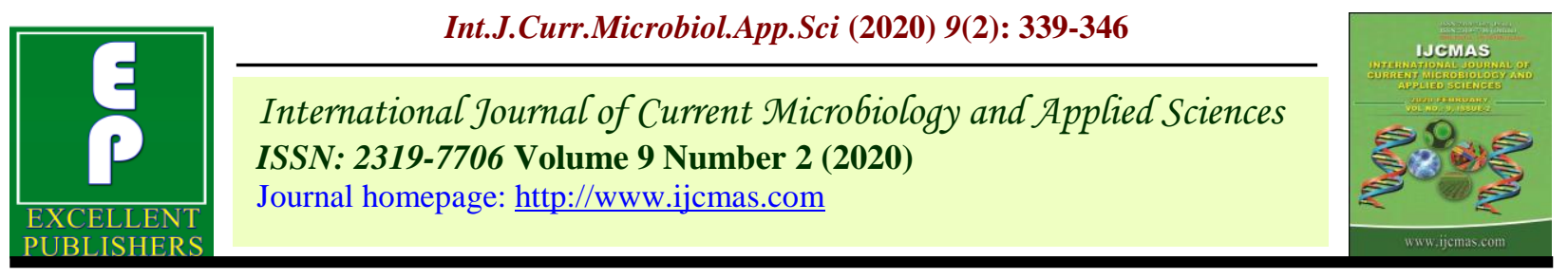

Original Research Article

https://doi.org/10.20546/ijcmas.2020.902.043

\title{
Efficiency of Two Common Spices against Green Gram Pathogen Rhizoctonia bataticola
}

\author{
Aarti R. Deshpande* \\ Department of Microbiology, Shankarlal Khandelwal College, Akola (Maharashtra), India \\ *Corresponding author
}

Keywords

Antagonistic activity, Cimomomum zeylanicum,

Rhizoctonia bataticola, Green gram, Cinnamon, Garlic ,Antifungal activity

Article Info

Accepted:

05 January 2020

Available Online:

10 February 2020

\section{A B S T R A C T}

Exploring eco-friendly fungitoxicants is a current need in the context of hazardous effects of chemical fungicides. In the present work, inhibitory effect of two common spices viz. cinnamon and garlic was evaluated against Rhizoctonia bataticola, a common soil borne pathogen of green gram. The inhibition of $R$. bataticola growth with different concentrations of both these spices was in the range of $26.25 \%$ to $100 \%$ by poisoned food technique. The inhibitory effect of different concentrations of carbendazim and copper oxychloride was in the range of $43.75 \&$ to $100 \%$. Autoclaving of the medium along with spices resulted in increase in growth inhibition of the pathogen as compared with the inhibition due to spices when added after autoclaving. Aqueous extracts prepared with boiling were more effective than the extracts prepared without boiling. Antagonistic potential of the spices was evaluated in terms of increase in seedling vigor index (SVI) of green gram seeds inoculated with $R$. bataticola by paper towel method. The increase in SVI was in the range of $25.85 \%$ to $45.03 \%$ with independent treatments of garlic and cinnamon to the pathogen inoculated seeds. SVI of the pathogen inoculated seeds increased by $30.43 \%$ with $1 \%$ carbendazim.

\section{Introduction}

A wide spread use of chemical fungicides for controlling phytopathogens has created imbalance in agricultural ecosystems leading to deterioration of soil health and productivity (Walia et al., 2014, Bacmaga et al., 2016). These chemical fungicides cause toxicity to non-target plants, animals and microbial life (Brauer et al., 2019) and also are causing extremely hazardous effects on human and animal health because of their carcinogenicity, mutagenicity and teratogenicity (Jasuja, 2015). In order to mitigate the problems due to extensive use of chemical fungicides there is growing interest 
in exploring the environment friendly alternatives for sustainable agricultural practices such as biofungicides and herbal fungicides. A wide variety of plant extracts and essential oils have been evaluated for their bioefficacy against many fungal photopathogen (Isman, 2000, Bhagwat and Datar, 2014,Suprapta 2016, Zambonelli, 2008).

Green gram (Vignaradia L.)is a legume crop with large cultivation in Asia and is a major crop in many states of India including Maharashtra. Fungal diseases cause yield losses of green gram upto 46-60\% (Kaur et $a l ., 2011)$. The soil and seed borne fungus Macrophomina phaseolina (Pycnidial stage of Rhizoctonia bataticola) causes root rot, collar rot, stem rot and leaf blight in green gram. Agallol, Captan, Thiram, Carbendazim and Thiophanate - methyl and benonyl are the chemical fungicides that have been evaluated to control Macrophomina phaseolina (Swamy et al., 2018).

In some studies plant extracts and their products have been assessed against green gram pathogens. (Javed and Amin, 2009, Murugapriya et al., 2011).Control of Macrophomina growth in- vitro and its incidences in green house conditions using plant based materials and their combination with other chemicals have also been reported (Pandey et al., 2018).

Garlic(Allium sativum) is a commonly used spice since ancient times and a medicinal herb that has wide spectrum of antimicrobial action (Harris et al., 2001).Similarly Cinnamon (Cinnamomum zeylanicum)is also a widely used spice having antibacterial (Nawabi et al., 2015) and antifungal properties (Ranshinghe et al., 2013)

The cost of production of any crop is directly influenced by the cost and amount of agricultural inputs. Overuse of chemical agroinputs increase the cost of crop production. The present work has been undertaken to evaluate the antifungal potential of two common species cinnamon and garlic against Rhizoctonia bataticola, a common soil borne pathogen of green gram.

An attempt has been made with the objective of assessing the fungi-toxic effect of powder of cinnamon ,juice of garlic and the aqueous extracts of these spices which may lead to development of simple domestic method of seed treatment to prevent crop loss due to seed and soil borne fungal phytopathogens.

\section{Materials and Methods}

\section{Poisoned Food Technique}

Requisite quantity of herbal powder/ extract / chemical fungicide was added in sterilized melted $\left(45^{\circ} \mathrm{C}\right)$ PDA separately so as to get test concentration. Chloramphenicol was added to prevent bacterial contamination. Flasks containing poisoned medium were shaken well to have even and uniform distribution of herbals and chemical fungicides and poured in petriplates. Fungal disk of $5 \mathrm{~mm}$ diameter cut from one week old fungus lawn culture was placed in the centre of the petriplate containing poisoned medium.

The control plate was kept where the fungal disc was grown under same conditions on plain PDA. Diameter of fungal growth was recorded on $3^{\text {rd }}, 4^{\text {th }}$, and $5^{\text {th }}$ day. The Vincent formula was used to calculate the percentage of inhibition of fungal growth.

$$
I=\frac{C-T \times 100}{C}
$$

Where

$\mathrm{I}=\%$ inhibition of growth

$\mathrm{C}=$ Growth of fungus in control

$\mathrm{T}=$ Growth of fungus in treatments 


\section{Preparation of aqueous extracts}

Total $25 \mathrm{~g}$ of each herbal powder was added in $200 \mathrm{ml}$ of distilled water and the extraction was carried out with boiling and at room temperature with shaking. The extracts were filtered through blotting paper and used for antifungal activity testing at three concentrations.

\section{Evaluation of Seedling Vigour Index}

\section{Germination paper method}

The seeds were germinated between two layers of germination papers which are placed in glass or plastic containers filled with water in required quantity.

The paper was not so wet that if pressed a film of water forms around the finger. Seeds were infected with fungal spores for maximum 2 hours and then treated with different concentrations of herbals and chemical antifungal agents for 30min. Seeds were arranged on the germination paper and covered with another sheet of germination paper.

Then the papers were rolled carefully and the rolls were dipped in container containing water for 10 days. After 10 days the results were noted in terms of \% germination, average root length $\&$ average shoot length. Seeds without inoculation of fungal pathogen and without treatment of antifungal agents served as control. Seedling vigor index were calculated for each treatment and control.

Seedling VigourIndex $=\%$ germination $\mathrm{x}$ (Root length + Shoot length)

\section{Results and Discussion}

Antifungal activity of $C$. zeylanicum bark powder was better than that of A. sativum juice of cloves at $0.1 \%$ and $0.5 \%$ concentration by poisoned food technique (Table-1). C. zeylanicum activity was better than A. sativum activity by $29.21 \%$ at $0.1 \%$ concentration and by $63.53 \%$ at $0.5 \%$ concentration of the fungitoxicant added before autoclaving.

Table.1 Effect of autoclaving on the antifungal activity of herbal and chemical fungi toxicants against Rhizoctonia batataticola by poisoned food technique.

\begin{tabular}{|c|c|c|c|c|}
\hline S.No. & Fungitoxicant & Concentration & After autoclaving & Before autoclaving \\
\hline $\mathbf{1}$ & A.sativum & $0.1 \%$ & $\mathrm{~nm}$ & 29.41 \\
\hline $\mathbf{2}$ & A.sativum & $0.5 \%$ & $\mathrm{~nm}$ & 36.47 \\
\hline $\mathbf{3}$ & C. zeylanicum & $0.1 \%$ & 26.25 & 41.18 \\
\hline $\mathbf{4}$ & C. zeylanicum & $0.5 \%$ & 48.75 & 100 \\
\hline $\mathbf{5}$ & Carbendazim & $0.1 \%$ & 43.75 & 52.94 \\
\hline $\mathbf{6}$ & Carbendazim & $0.5 \%$ & 100 & 100 \\
\hline $\mathbf{7}$ & Copper oxychloride & $0.1 \%$ & 78.75 & 81.17 \\
\hline $\mathbf{8}$ & Copper oxychloride & $0.5 \%$ & 100 & 100 \\
\hline
\end{tabular}

Note : $\mathrm{nm}=$ Not measurable 
Table.2 Efficacy of herbal and chemical fungi toxicants on SVI of green gram seeds inoculated with Rhizoctonia batataticola.

\begin{tabular}{|c|c|c|c|c|c|c|}
\hline S.No. & Fungitoxicant & Concentration & Germination (\%) & ARL (cm) & ASL (cm) & SVI \\
\hline 1 & Control & - & 78 & 8.65 & 5.51 & 1164.48 \\
\hline 2 & Fungus $(\mathrm{F})$ infected & - & 49 & 8.29 & 0.06 & 763.15 \\
\hline 3 & $(\mathrm{~F})+$ A. sativum & $1 \%$ & 70 & 9.47 & 5.53 & 1050 \\
\hline 4 & $(\mathrm{~F})+$ A. sativum & $10 \%$ & 66 & 9.66 & 4.75 & 948.42 \\
\hline 5 & $(\mathrm{~F})+C$. zeylanicum & $1 \%$ & 72 & 10.45 & 7.31 & 1279.38 \\
\hline 6 & $(\mathrm{~F})+C$. zeylanicum & $10 \%$ & 68 & 9.65 & 6.82 & 1120.79 \\
\hline 7 & $\begin{array}{c}(\mathrm{F})+(\text { A. sativum }+C . \\
\text { zeylanicum })\end{array}$ & $10 \%$ & 76 & 9.60 & 7.67 & 1312.52 \\
\hline 8 & $(\mathrm{~F})+$ Carbendazim & $1 \%$ & 68 & 9.35 & 6.77 & 1096.99 \\
\hline
\end{tabular}

Note: ARL- Average root length, ASM- Average shoot length, SVI-Seedling Vigor Index

The antifungal activities of carbendazim and copperoxychloride were better than the herbal fungitoxicants at $0.1 \%$ concentration whereas at $0.5 \%$ concentration $100 \%$ inhibition was obtained by C.zeylanicum and both the chemical fungitoxicants. Among the two chemical fungitoxicants, copper oxychloride was better than carbendazim at $0.1 \%$ concentration (Table-1).

The inhibitory activity of spices were far better when the powders were added before autoclaving than the inhibitory activity of spices added after autoclaving. This indicates better extraction of fungitoxicants at high temperature with pressure. Moreover the fungitoxic components were thermostable.

Kishore and Pande in 2007 has reported the broad spectrum antifungal activity of cinnamon essential oil against 14 different phytopathogenic fungi including $R$. bataticola. Ransinghe et al. (2002) have also reported the antifungal activity of $C$. zeylanicum against some other plant pathogenic fungi. Most of such studies were focused on the fungitoxic potential of essential oil of C. zeylanicum. Present studies were carried out using powder of commercially available bark of $C$. zeylanicum from farmer's point of view.

Kutawa et al., (2018) had assessed the fungitoxic potential of A. sativum against Fusarium and Rhizopus and had reported the superior action of its ethanolic extract than aqueous extract. Present investigations demonstrated the inhibitory potential of $A$. sativum juice of cloves at $0.1 \%$ concentration against $R$. bataticola when added before autoclaving of the medium.

Aqueous extracts of the spices were inhibitory for the growth of $R$. bataticola. The extract prepared with boiling outperformed the extracts prepared without boiling (Figure -1, Plate-1). The inhibitory potential of $C$. zeylanicum extracts was better than that of $A$. sativum extracts. C. zeylanicum $10 \%$ extract prepared with boiling resulted in highest degree of inhibition (95.18\%) among all the tested fungi toxic preparations. 
Effect of independent and combined seed applications of $C$. zeylanicum powder and $A$. sativum juice was assessed on the seedling vigor index (SVI) of $R$. bataticola inoculated green gram seeds by paper towel method (Table -2).Pathogen inoculation resulted in $36.33 \%$ decrease in SVI over control.

Treatment of the pathogen inoculated seeds with $A$. sativum and $C$. zeylanicum at $1 \%$ and $10 \%$ concentration by weight of seeds increased SVI in the range of $25.85 \%$ to $45.03 \%$ over infected control. It was interesting to note that the performance of $1 \%$ spices concentration was better than that of $10 \%$ spices concentration suggesting that high concentration of spices may have been detrimental for the process of germination and seedling growth.

Combined treatment with spices at $10 \%$ concentration of 1:1 mixture resulted in $45.35 \%$ increase in SVI whereas independent treatment of A. sativum (10\%) and C. zeylanicum (10\%) produced $25.85 \%$ and $37.26 \%$ increase in the SVI of pathogen inoculated green gram seeds respectively (Figure-2).

All the above findings suggest that independent seed treatment with both the spices at $1 \%$ concentration appeared to be effective in overcoming $R$. bataticola infection of green gram seeds. Their combined seed application also appeared to be effective.

Kishore and Pande (2007) had tested foliar spray, seed treatments and soil amendment of C. zeylynicum essential oil for control of late leaf spot and crown rot diseases of peanut and had found only soil amendment as effective method for the disease control. They had stated the impracticality of the soil amendment with essential oil.

Present work demonstrated the efficacy of independent or combined seed treatment with garlic and/or cinnamon for increase in SVI of $R$. bataticola inoculated green gram seeds. However intensive studies are required in future to validate the application potential of seed treatment with thesespices under field conditions.

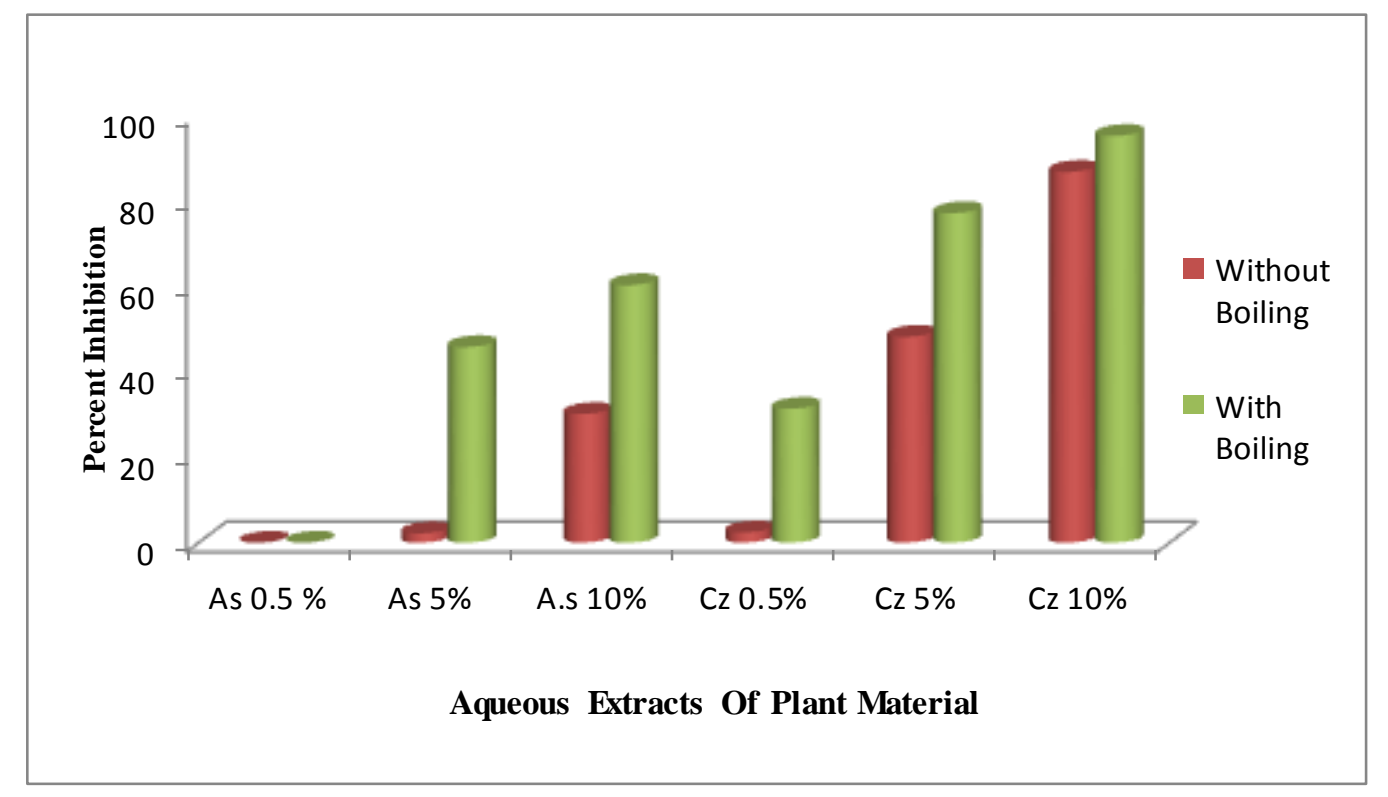

Note:As=Allium sativum $C z .=$ Cinnamomumzeylanicum 
Figure.1 Antifungal activity of aqueous extracts against Rhizoctonia bataticola



Note : A.s. $=$ Allium sativum C.z. $=$ Cinnamomumzeylanicum

Figure.2 Percent increase in SVI of $R$. bataticola inoculated seeds with different treatments.

Plate.1 Antifungal activity of aqueous extracts of Allium sativum and chemical fungitoxicants against Rhizoctonia bataticola by poisoned food technique

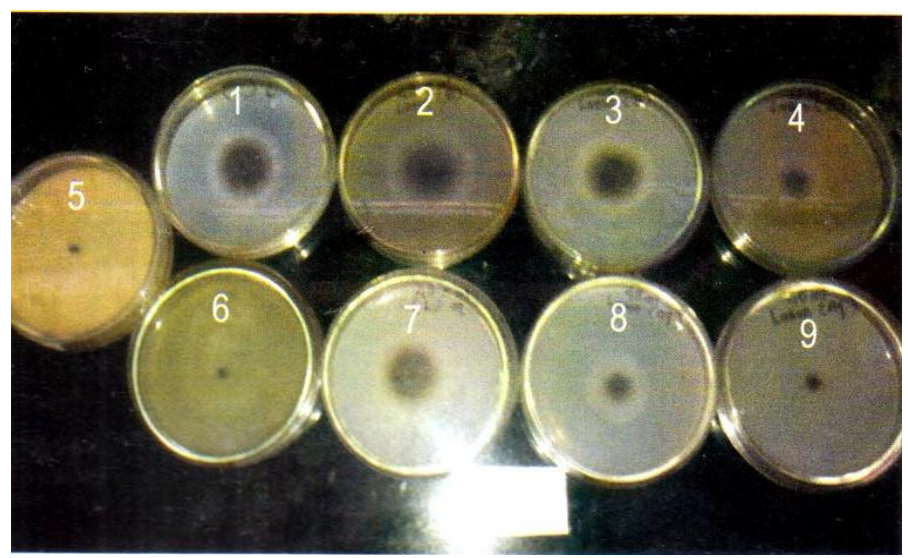

Control ; 2,3,4-0.5\%,5\% and $10 \%$ extract prepared without boiling respectively 5-0.5\% Carbendazim; 6-0.5\%Copperoxychloride; $7,8,9-0.5 \%, 5 \%$ and $10 \%$ extract prepared with boiling respectively

Cinnamon powder and garlic juice as well as their aqueous extracts were effective for growth inhibition of $R$. bataticola in-vitro. Autoclaving or boiling considerably improved the performance of the spices regarding their inhibitory activity against the pathogen. Seed treatment with the powder of cinnamon and the juice of garlic were effective for increasing SVI of the pathogen inoculated green gram seeds under laboratory conditions. Combined application of garlic and cinnamon 1:1 mixture at $10 \%$ concentration was also an 
effective treatment which produced improvement in SVI of the pathogen inoculated green gram seeds under experimental conditions.

Their performance under field conditions needs to be assessed in order to validate their application potential.

\section{Acknowledgements}

The author is thankful to Shankarlal Khandelwal College, Akola for providing necessary facilities for the research work and Dr. B. T. Raut, Ex. Head Dept. of Plant pathology, Dr. Panjabrao Deshmukh Krishi Vidyapeeth, Akola for his expert suggestions.

\section{References}

Bacmaga, M., Jadwiga W. and Jan K. (2016) The effect of the Falcon 460 EC fungicide on soil microbial communities, enzyme activities and plant growth. Ecotoxicology, 25(8); 1575-1587.

Bhagwat, M. R. and Datar A. G. (2014). Antifungal activity of herbal extracts against plant pathogenic fungi. Archieves of Phytopathology and plant protection.Vol. 47(8); 959-965.

Brauer V S, Rezende CP, Pessoni AM, et al., (2019). Antifungal Agents in Agriculture: Friends and Foes of Public Health. Biomolecules, 9, 521.

Haris J. C., Plummer S, Lloyd D, Cottrell S,(2001). Antimicrobial properties of Allium sativum (garlic). Applied Microbiology and Biotechnology, 57(3): 282-6.

Isman B M 2000, Plant essential oils for pest and disease management, Crop Prot, 19:603-608

Jasuja. N. D. (2015). A Review on Toxicological Effects of Fungicides. Research Journal of Pharmaceutical,
Biological and Chemical Sciences, 6(2): 348-360.

Javed, A. and Amin, M. (2009). Antifungal activity of methanol and n-hexane extracts of three Chenopodium species against Macrophomina phaseolina. Nat. Prod. Res. 23, 1120-1127.

Kaur, L., Singh, P., and Sirari, A. (2011).Biplot analysis for locating multiple disease resistant diversity in mungbean germplasm. Disease Res. 26, $55-60$.

KishorG.K. and PandeS.(2007). Evaluation of Essential Oils and Their Components of Broad-Spectrum Antifungal Activity and Control of Late Leaf Spot and Crown Rot Diseases in Peanut.Plant Disease, 375.

Kutawa A. A. B., Musa D.D., Haruna A. (2018). Antifungal Activity of Garlic (Allium sativum) extract on some selected fungi. Journal of Medicinal Herbs and Ethnomedicine, 4: 12-14.

Murugapriya, E., Alice, D., and Jayamani, P. (2011).Antifungal activity of botanicals and micronutrients against Macrophomina leaf blight in mungbean. J. Food Leg. 24, 113-116.

Nabavi SF, Lorenzo AD, Izadi M, SobarzoSanchez E, Daglia M, and Nabavi SM. Nutrients, 7(9); 7729-7748 (2015).

Pandey, A. K., Burlakoti, R. R., Kenyon, L., Nair, R. M. (2018). Perspective and challenges for sustainable management of fungal diseases of mungbean (Vigna radiate (L.)) : a review. Fron. Environ. Sci., 6, p. 53.

Ranasinghe P., Pigera S., Premakumara S. Galappaththy, P. Constantinue G. R. and Katulanda P. (2013).Medicinal properties of true Cinnamon (Cinnamomum zeylanicum) a systematic review. BMC Complementary and Alternative Medicine, 13: 275.

Ransinghe L, Jayawardena B, Abeywickrama K, (2002). Fungicidal activity of 
essential oils of Cinnamomum zeylanicum (L.) and Syzygium aromaticum (L) Merret L. M. Perry against crow rot and anthracnose pathogens isolated from banana. Lett. Appl. Microbiol. vol 35:3.

Suprapta D. N. (2016).A review of tropical plants with Antifungal Activities against Plant Fungal Pathogens.Preprints 2016, 100049.

Swamy, C., M. K. Naik, Y. S. Amaresh and S. K. Jayalakshmi (2018).Evaluation of Fungicides and Bio-agents under in vitro Condition against Macrophomina phaseolina Causing Stem Canker of Pigeonpea. International Journal of
Current Microbiology and Applied Sciences, Vol. 8, No. 01.811-819.

WaliaA, Mehta P, Guleria S, Chauhan A and Shirkot C. K. (2014). Impact of fungicide Mancozeb at different application Rates on Soil Microbial Populations, Soil biological Processes and Enzyme Activities in Soil.The Scientific World Journal Vol. 2014, article ID 702909 http://dx.doi.org/10.1155/2014/702909

Zambonelli A ,D'Aulerio AZ, Bianchi A, Albasini AJ., (2008). Effects of Essential Oils on Phytopathogenic Fungi In vitro. Journal of Phytopathology, 144(9-10): 491-494.

\section{How to cite this article:}

Aarti R. Deshpande. 2020. Efficiency of Two Common Spices against Green Gram Pathogen Rhizoctonia bataticola. Int.J.Curr.Microbiol.App.Sci. 9(02): 339-346.

doi: https://doi.org/10.20546/ijcmas.2020.902.043 